\title{
DERAJAT MEROKOK DENGAN DISABILITAS LOW BACK PAIN PADA TENAGA KERJA BONGKAR MUAT DI PELABUHAN KOTA KENDARI
}

\author{
${ }^{1}$ Iriamana Liasyarah Marudin, ${ }^{2}$ Muh. Rustam HN, ${ }^{3}$ La Ode Alifariki* ${ }^{4}$ Adius Kusnan \\ 1 Program Studi Kedokteran FK UHO \\ 2 Fakultas Kedokteran Universitas Halu Oleo \\ 3 Bagian Epidemiologi Fakultas Kedokteran Universitas Halu Oleo \\ *Email: ners_riki@yahoo.co.id
}

\begin{abstract}
ABSTRAK
Latar belakang: Nyeri punggung bawah adalah kondisi yang tidak menyenangkan atau nyeri yang dapat membatasi aktivitas dan Low back pain adalah penyebab utama kecacatan di dunia. Berdasarkan data dari Kantor Kesehatan Pelabuhan pada tahun 2018, Low back pain adalah suatu kondisi yang sering dialami oleh pekerja bongkar muat di Pelabuhan Kendari. Ada banyak faktor yang bisa memengaruhi nyeri punggung bawah, salah satunya adalah merokok. Penelitian ini bertujuan untuk mengetahui hubungan derajat merokok dengan kecacatan nyeri punggung bawah. Metode Penelitian ini merupakan penelitian analitik observasional dengan pendekatan cross-sectional. Penelitian ini merupakan penelitian analitik observasional dengan pendekatan cross-sectional. 130 sampel diperoleh melalui total sampling. Data dianalisis menggunakan uji korelasi Spearman (nilai $p<0,05$ ). Hasil penelitian menunjukkan bahwa mayoritas responden memiliki kebiasaan merokok ringan $70,8 \%$ dan cacat ringan $42,3 \%$. Berdasarkan uji statistik, diperoleh korelasi positif antara derajat merokok dan disabilitas nyeri punggung bawah pada pekerja bongkar muat di pelabuhan Kota Kendari dengan nilai $p=0,000$ dan koefisien korelasi $=0,524$. Kesimpulan dari penelitian ini adalah bahwa ada hubungan yang signifikan antara tingkat merokok dan kecacatan nyeri punggung bawah pada tenaga kerja bongkar muat di pelabuhan Kota Kendari.
\end{abstract}

Kata kunci: Low back pain, Kecacatan Nyeri Punggung, Derajat Merokok

\section{ABSTRACT}

Background : Low back pain is unpleased condition or pain which can make limitation in activity and Low back pain is a leading cause of disability in the world. Based on data from the Port Health Office in 2018, Low back pain is a condition that is often experienced by loading and unloading workers in the Port of Kendari. There are many factors that can affect low back pain, one of which is smoking. This study aimed to determine the relationship of smoking degree with low back pain disability. Method: This research is an observasional analytic study with cross-sectional approach. This research is an observasional analytic study with cross-sectional approach. 130 sampels were acquired through total sampling. Data were analyzed using the Spearman correlation test ( $p$ value $<0,05)$. Result : The result of the study showed that the majority of respondents have mild smoking habits of $70,8 \%$ and mild disabilities of $42,3 \%$. Based on statistical test, a positive correlation was obtained between of smoking degree and low back pain disability of loading and unloading workers in port of Kendari City with $p$ value $=0,000$ and a correlation coefficient $=0.524$. Conclusion : The conclusion of this study is that there is a significant correlation between smoking degree and low back pain disability of tenaga kerja bongkar muat in port of Kendari City.

Keywords: Low back pain, Low Back Pain Disability, Smoking Degree

\section{PENDAHULUAN}

Low back pain (LBP) adalah suatu kondisi yang tidak mengenakan atau nyeri kronik dengan keluhan minimal 3 bulan yang disertai adanya keterbatasan aktivitas yang diakibatkan nyeri apabila melakukan pergerakan atau mobilisasi (Helmi, 2013). Berdasarkan Studi Global Burden of Disease (2010), LBP menduduki peringkat tertinggi di dunia dalam hal disabilitas dengan prevalensi $9,4 \%$. Jumlah kasus LBP meningkat dari 58,2 juta pada tahun 1990 menjadi 83,0 juta pada tahun 2010 . Selain itu, dari 291 penyakit yang diteliti, LBP merupakan penyumbang terbesar kecacatan global yang diukur melalui Years Lived with Disability (YLD) (Hoy, D., March
L., Brooks, P., Blyth, F., Woolf, A., Bain, C., n.d.).

Data untuk jumlah penderita LBP di Indonesia masih belum diketahui secara pasti, namun diperkirakan penderita LBP di Indonesia bervariasi antara $7,6 \%-37 \%$ dari jumlah penduduk yang ada di Indonesia (Rohmawan, Eko Arma., Haryono, 2017). Penelitian yang dilakukan Kelompok Studi Nyeri PERDOSSI (Perhimpunan Dokter Spesialis Saraf Indonesia) pada 14 rumah sakit pendidikan di Indonesia, pada bulan Mei 2002 menunjukkan jumlah penderita nyeri sebanyak 4.456 orang ( $25 \%$ dari total kunjungan), dimana 1.598 orang $(35,86 \%)$ adalah penderita LBP (Riningrum, Hanif., Widowati, 2016). 
Salah satu faktor yang berhubungan dengan kejadian LBP adalah kebiasaan merokok. Dalam laporan resmi WHO, jumlah kematian akibat merokok tiap tahun adalah 4,9 juta orang per tahunnya. Hubungan yang signifikan antara kebiasaan merokok dengan keluhan LBP terutama untuk pekerjaan yang memerlukan pengerahan otot karena nikotin pada rokok dapat menyebabkan berkurangnya aliran darah ke jaringan. Selain itu, merokok dapat pula menyebabkan berkurangnya kandungan mineral pada tulang sehingga menyebabkan nyeri akibat terjadinya keretakan atau kerusakan pada tulang (Hadyan, 2015). Pada studi yang dilakukan oleh Sitepu pada 32 orang petani jeruk di Desa Dokan dimana terdapat hubungan antara merokok dengan kejadian LBP.

Berdasarkan uraian diatas, penulis tertarik untuk melakukan penelitian mengenai hubungan derajat merokok dengan disabilitas low back pain pada tenaga kerja bongkar muat di Pelabuhan Kota Kendari.

\section{METODE PENELITIAN}

Jenis penelitian ini yaitu analitik observasional dengan menggunakan rancangan penelitian cross sectional study. Penelitian ini dilaksanakan pada bulan November sampai Desember 2018 di Pelabuhan Kota Kendari dan Koperasi Karya Bahari Kota Kendari. Teknik pengambilan sampel yang digunakan dalam penelitian ini adalah total sampling yaitu 130 responden yang memenuhi syarat kriteria inklusi dan kriteria eksklusi.

Pengumpulan data dilakukan dengan mewawancarai responden dengan menggunakan kuesioner identitas, Nordic Body Map untuk melihat ada tidaknya keluhan low back pain dan dilanjutkan dengan kuesioner Oswestry Disability Index untuk menilai disabilitas yang diakibatkan low back pain yang dialami. Analisis data dilakukan dengan menggunakan uji statistik Spearmen dengan nilai $p<0,05$ (Arikunto, 2010). Penelitian ini telah mendapatkan persetujuan dari Komisi Etik Penelitian Kesehatan Lembaga Penelitian dan Pengabdian pada Masyarakat Universitas Halu Oleo.

\section{HASIL}

\section{Analisis Univariat}

Tabel 1 menunjukan hasil penelitian mengenai distribusi frekuensi komponen penelitian meliputi usia, indeks massa tubuh, masa kerja, lama kerja, derajat merokok dan disabilitas LBP pada 130 responden. Hasil penelitian ini menunjukan bahwa pada kelompok usia 26-35 tahun sebanyak 26 orang (20\%), usia 36-45 tahun sebanyak 42 orang $(32,3 \%)$, usia $46-55$ tahun sebanyak 54 orang $(41,5 \%)$ dan usia $56-65$ tahun sebanyak 8 orang $(6,2 \%)$. Pada pengukuran IMT, didapatkan sebanyak 13 orang $(10 \%)$ dengan berat badan kurang, sebanyak 65 orang $(50 \%)$ dengan berat badan normal dan sebanyak 52 orang $(40 \%)$ dengan berat badan lebih. Berdasarkan masa kerja, menunjukan bahwa dari jumlah sampel dalam penelitian ini sebanyak 130 orang dengan masa kerja $\leq 13$ tahun tahun sebanyak 23 orang $(17,7 \%)$ dan masa kerja $>13$ tahun sebanyak 107 orang $(82,3 \%)$. Selain itu, berdasarkan lama kerja menunjukan bahwa sebanyak sebanyak 64 orang $(49,2 \%)$ dengan lama kerja $<8$ jam dan sebanyak 66 orang $(50,8 \%)$ dengan lama kerja $\geq 8 \mathrm{jam}$. Berdasarkan kebiasaan merokok, responden yang memiliki derajat merokok ringan yaitu sebanyak 92 orang $(70,8 \%)$ dan derajat merokok berat sebanyak 38 orang $(29,9 \%)$ dan juga yang tidak mengalami disabilitas yaitu sebanyak 43 orang $(33,1 \%)$, disabilitas ringan sebanyak 55 orang $(42,3 \%)$, disabilitas sedang sebanyak 31 orang $(23,8 \%)$, disabilitas berat sebanyak 1 orang $(0,7 \%)$ dan tidak ada yang mengalami disabilitas total.

\section{Analisis Bivariat}

Hasil penelitian ini menunjukan bahwa responden yang memiliki derajat merokok ringan dengan tidak disabilitas sebanyak 39 orang $(30 \%)$, derajat merokok ringan dengan disabilitas ringan sebanyak 46 orang $(35,4 \%)$, derajat merokok ringan dengan disabilitas sedang sebanyak 6 orang $(4,6 \%)$ dan derajat merokok ringan dengan disabilitas berat sebanyak 1 orang $(0,8 \%)$ lalu diikuti dengan derajat merokok berat dengan tidak disabilitas sebanyak 4 orang $(3,1 \%)$, derajat merokok berat dengan disabilitas ringan sebanyak 25 orang $(6,9 \%)$ dan derajat merokok berat dengan disabilitas sedang sebanyak $(19,2 \%)$.

Berdasarkan penelitian ini, pada tabel 2 menunjukkan presentasi tertinggi didapatkan pada responden yang mengalami disabilitas ringan dengan derajat merokok ringan yaitu sebanyak 46 orang $(35,4 \%)$. 
Berdasarkan hasil analisis uji statistik didapatkan nilai $p=0,000$ yang mana terdapat hubungan yang signifikan karena nilai $p$ lebih kecil dari 0,05 . Sehingga dapat disimpulkan bahwa terdapat hubungan yang bermakna antara derajat merokok dengan disabilitas LBP dimana nilai coefficient corelation 0,524 yaitu hubungan dengan kekuatan sedang. Adanya hubungan antara keduanya maka $\mathrm{HO}$ ditolak dan $\mathrm{Ha}$ diterima.

\section{PEMBAHASAN \\ Hubungan Derajat Merokok dengan Disabilitas Low Back Pain}

Hasil penelitian ini sejalan dengan penelitian yang di lakukan oleh Lincoln (2003) mengenai hubungan merokok dengan disabilitas musculoskeletal dimana didapatkan hasil terdapat hubungan antara derajat merokok dengan disabilitas musculoskeletal dengan LBP sebagai penyakit terbesar pada bagian musculoskeletal disorder pada penelitian ini. Perokok berat memiliki kumulatif tertinggi risiko disabilitas $(17,6 \%)$, diikuti oleh perokok moderat $(15,8 \%)$, bukan perokok $(12,2 \%)$ dan kemudian mantan perokok $(10,3 \%)$. Selain itu, penelitian lain yang dilakukan oleh Prasarn (2012) menunjukan bahwa terdapat hubungan yang signifikan antara riwayat merokok dengan disabilitas LBP yang diukur menggunakan Oswestry Disability Indeks (ODI) dimana skor ODI terburuk dilaporkan oleh perokok saat ini $(44,33 \%)$, diikuti oleh perokok sebelumnya $(38,11 \%)$, dan terakhir oleh bukan perokok $(36.02 \%)$ (Prasarn, Mark L., Horodyski, Mary B., Behrend, Caleb., Wright, John., Rechtine, 2012).

Hubungan yang signifikan antara kebiasaan merokok dengan keluhan LBP terutama untuk pekerjaan yang memerlukan pengerahan otot karena nikotin pada rokok dapat menyebabkan berkurangnya aliran darah ke jaringan. Selain itu, merokok dapat pula menyebabkan berkurangnya kandungan mineral pada tulang sehingga menyebabkan nyeri akibat terjadinya keretakan atau kerusakan pada tulang (Hadyan, 2015).

Kandungan nikotin dalam rokok menyebabkan vasokonstriksi pembuluh darah yang mensuplai nutrisi ke sel-sel diskus intervertebralis, bila pasokan nutrisi terganggu sel-sel mengalami malnutrisi sehingga rentan mengalami kerusakan. Kandungan nikotin di dalam rokok juga mengakibatkan penebalan dinding pembuluh darah yang memperberat pasokan darah dan nutrisi ke jaringan. Salah satu hasil akhir rokok adalah gas beracun karbon monoksida. Karbon monoksida yang dihasilkan dari pembakaran rokok akan berikatan dengan hemoglobin $(\mathrm{Hb})$, sehingga menghambat dan juga mengurangi pelepasan oksigen (yang seharusnya berikatan dengan hemoglobin) ke jaringan terutama jaringan sel-sel diskus intervertebralis yang kekurangan nutrisi. Selain itu, nikotin mempunyai efek negatif terhadap sel osteoblas, yaitu mempengaruhi proliferasi dan juga metabolisme seluler osteoblas serta sintesis kolagen, sehingga kepadatan mineral tulang berkurang (Patrianingrum, Meliani., Oktaliansah, Ezra., Surahman, 2015).

Ketika terhirup ke dalam tubuh, kandungan nikotin dalam rokok mempengaruhi aktivitas dua protein yang berhubungan dengan proses pembentukan tulang. Kedua protein tersebut adalah osteoblast dan osteoclast. Pada perokok, aktivitas osteoclast cenderung meningkat sementara osteoblast cenderung melambat. Tulang mengalami remodeling berkesinambungan melalui siklus perusakan dan pembentukan. Remodeling diperantarai oleh keseimbangan antara osteoclast yang meresorpsi tulang dan osteoblas yang membentuk tulang baru. Pengaruh nikotin terhadap seluler tulang adalah mengganggu keseimbangan antara pembentukan dan resorpsi tulang. Nikotin menghambat pembentukan osteoblas dan merangsang pembentukan osteoclast sehingga tulang rentang mengalami kerusakan (Rocha, 2011).

Secara patologis jika terjadi kerusakan berbagai jaringan dan ujung ujung serabut saraf maka terjadi pelepasan mediator kimiawi serta neurotransmiter berupa $\mathrm{H}+, \mathrm{K}+, 5-\mathrm{HT}, \mathrm{PG}$, bradikinin, histamin, neuropeptida seperti SP, sitokin, purin, eikosanaid dan intraseluler. Mediator ini nantinya akan berikatan dengan reseptor spesifik di perifer diserabut saraf sensorik disekitar ujung-ujung saraf yang nantinya melalui proses transduksi,transmisi dan modulasi akan sampai ke daerah korteks sensorik dan dipersepsikan oleh otak sebagai nyeri (Purba, Jan S., Rumawas, 2006).

Nyeri dapat menyebabkan impairment dan disabilitas. Impairment adalah abnormalitas atau hilangnya fungsi anatomik, fisiologik, maupun psikologik 
sedangkan disabilitas adalah hasil dari impairment yaitu keterbatasan atau gangguan kemampuan untuk melakukan aktivitas sehari-hari.

Nyeri yang dialami ini dapat membatasi pekerjaan dan kemampuan fungsional pekerja yang biasanya menjadi penyebab seseorang menjadi pensiun dini dari pekerjaannya terutama pada pekerjaan yang membutuhkan tenaga dan pengerahan otot.

\section{KESIMPULAN}

Berdasarkan hasil analisis data dari penelitian yang di lakukan, dapat di simpulkan bahwa terdapat hubungan antara derajat merokok dengan disabilitas low back pain pada TKBM Pelabuhan Kota Kendari.

\section{SARAN}

Bagi perusahaan peneliti menyarankan untuk memperhatikan faktor faktor resiko yang berhubungan dengan kejadian low back pain terutama pada faktor individunya agar bisa mencegah terjadinya low back pain bagi para pekerjanya. Selain itu, perlu adanya perhatian bagi kesehatan pekerja dengan mendaftarkan para pekerja ke asuransi kesehatan agar bisa mendapat jaminan kesehatan kedepannya. Bagi peneliti selanjutnya disarankan agar penelitian terhadap faktor risiko individu seperti aktivitas fisik, faktor risiko pekerjaan seperti posisi kerja, beban kerja serta faktor risiko lingkungan seperti getaran dan kebisingan sebaiknya di lakukan untuk penelitian selanjutnya agar bisa menjadi perbandingan untuk melihat faktor resiko mana yang paling berpengaruh terhadap terjadinya low back pain ini. Bagi pekerja peneliti menyarankan bagi pekerja yang merokok, disarankan untuk berhenti merokok atau mengurangi konsumsi rokok.

\section{DAFTAR PUSTAKA}

Arikunto. (2010). Prosedur Penelitian Suatu Pendekatan Praktik. Jakarta: Rineka Cipta.

Hadyan, M. F. (2015). Faktor - Faktor yang Mempengaruhi Kejadian Low Back
Pain pada Pengemudi Transportasi Publik. Jurnal MAJORITY, 4(7), 19-24. Helmi, Z. N. (2013). Buku Ajar Gangguan Muskuloskeletal. Jakarta: Salemba Medika.

Hoy, D., March L., Brooks, P., Blyth, F., Woolf, A., Bain, C., dkk. (n.d.). The Global Burden Of Low Back Pain: Estimates From The Global Burden of Disease 2010 study. Ann Rheum Dis, 73, 968-974.

Patrianingrum, Meliani., Oktaliansah, Ezra., Surahman, E. (2015). Prevalensi dan Faktor Resiko Nyeri Punggung Bawah di Lingkungan Kerja Anastesiologi Rumah Sakit Dr. Hasan Sadikin Bandung. Jurnal Anastesi Perioperatif, 3(1), 47-56.

Prasarn, Mark L., Horodyski, Mary B., Behrend, Caleb., Wright, John., Rechtine, G. R. (2012). Negative effects of smoking, workers compensation, and litigation on pain/disability scores for spine patients. International Journal Of Neurosurgery And Neurosciences, 3, 366-369.

Purba, Jan S., Rumawas, A. M. (2006). Nyeri Punggung Bawah:Studi Epidemiologi, Patofisologi dan Penanggulangan. Jurnal Berkala Neuorsains, 7(2).

Riningrum, Hanif., Widowati, E. (2016). Pengaruh Sikap Kerja, Usia, Dan Masa Kerja Terhadap Keluhan Low Back Pain. Jurnal Pena Medika, 6(2), 91102.

Rocha, M. I. . (2011). Nicotine effects on bone metabolism: in vitro studies with human osteoclasts and co-cultures osteoclasts and osteoblasts in an hydroxyapatite surface.

Rohmawan, Eko Arma., Haryono, W. (2017). Masa Kerja, Sikap Kerja Dan Keluhan Low Back Pain Pada Pekerja Bagian Produksi PT Surya Besindo Sakti Serang. In Peran Tenaga Kesehatan dalam Pelaksanaan SDGs. Jakarta: Universias Ahmad Dahlan. 
Tabel 1.

Distribusi frekuensi data penelitian

\begin{tabular}{|c|c|c|c|}
\hline No. & Variabel & Frekuensi & Presentase \\
\hline 1. & $\begin{array}{l}\text { Usia } \\
26-35 \\
36-45 \\
46-55 \\
56-65\end{array}$ & $\begin{array}{r}26 \\
42 \\
54 \\
8\end{array}$ & $\begin{array}{c}20 \% \\
32,3 \% \\
41,5 \% \\
6,2 \%\end{array}$ \\
\hline 2. & $\begin{array}{l}\text { IMT } \\
\text { Berat Badan Kurang } \\
\text { Berat Badan Normal } \\
\text { Berat Badan Lebih }\end{array}$ & $\begin{array}{l}13 \\
65 \\
52\end{array}$ & $\begin{array}{l}10 \% \\
50 \% \\
40 \%\end{array}$ \\
\hline 3. & $\begin{array}{l}\text { Masa Kerja } \\
\leq 13 \text { Tahun } \\
>13 \text { Tahun }\end{array}$ & $\begin{array}{c}23 \\
107\end{array}$ & $\begin{array}{l}17,7 \% \\
82,3 \%\end{array}$ \\
\hline 4. & $\begin{array}{l}\text { Lama Kerja } \\
<8 \text { Jam } \\
\geq 8 \text { Jam }\end{array}$ & $\begin{array}{l}64 \\
66\end{array}$ & $\begin{array}{l}49,2 \% \\
50,8 \%\end{array}$ \\
\hline 5. & $\begin{array}{l}\text { Derajat Merokok } \\
\text { Derajat Ringan } \\
\text { Derajat Berat }\end{array}$ & $\begin{array}{l}92 \\
38\end{array}$ & $\begin{array}{l}70,8 \% \\
29,2 \%\end{array}$ \\
\hline 6. & $\begin{array}{l}\text { Tingkat Disabilitas LBP } \\
\text { Tidak Disabilitas } \\
\text { Disabilitas Ringan } \\
\text { Disabilitas Sedang } \\
\text { Disabilitas Berat } \\
\text { Disabilitas Total }\end{array}$ & $\begin{array}{c}43 \\
55 \\
31 \\
1 \\
0\end{array}$ & $\begin{array}{c}33,1 \% \\
42,3 \% \\
23,8 \% \\
0,8 \% \\
0 \%\end{array}$ \\
\hline & Total & 130 & $100 \%$ \\
\hline
\end{tabular}

Tabel 2.

Hubungan antara derajat merokok dengan disabilitas LBP pada TKBM di Pelabuhan Kota Kendari.

\begin{tabular}{|c|c|c|c|c|c|c|c|c|c|c|c|}
\hline \multirow{3}{*}{ Merokok } & \multicolumn{10}{|c|}{ Disabilitas } & \multirow{3}{*}{$P$} \\
\hline & \multicolumn{2}{|c|}{ Tidak } & \multicolumn{2}{|c|}{ Ringan } & \multicolumn{2}{|c|}{ Sedang } & \multicolumn{2}{|c|}{ Berat } & \multicolumn{2}{|c|}{ Total } & \\
\hline & $\mathrm{n}$ & $\%$ & $n$ & $\%$ & $\mathrm{~N}$ & $\%$ & $\mathrm{~N}$ & $\%$ & $\mathrm{n}$ & $\%$ & \\
\hline $\begin{array}{l}\text { Derajat } \\
\text { Ringan }\end{array}$ & 39 & $30 \%$ & 46 & $35,4 \%$ & 6 & $4,6 \%$ & 1 & $0,8 \%$ & 0 & $0 \%$ & \\
\hline $\begin{array}{c}\text { Derajat } \\
\text { Berat }\end{array}$ & 4 & $3,1 \%$ & 9 & $6,9 \%$ & 25 & $19,2 \%$ & 0 & $0 \%$ & 0 & $0 \%$ & \\
\hline Total & 43 & $33,1 \%$ & 55 & $42,3 \%$ & 31 & $23,8 \%$ & 1 & $0,8 \%$ & 0 & $0 \%$ & \\
\hline
\end{tabular}

